\title{
THE EVOLUTION OF GENRE IN THE WRITING PROCESS
}

\author{
Raelke Grimmer | Flinders University
}

\begin{abstract}
Categorising works by genre can be controversial in literature. Margaret Atwood and Kazuo Ishiguro are two examples of writers who have been vocal in denouncing the genre their works have been boxed into. Yet genre is an essential part of the writing process, because specific language, styles and structures are used within different social contexts to communicate purpose. This paper is a practice-led study that analyses the evolution in genre of what became a memoir, to illustrate how experimenting with different genres shaped the final form, structure and genre of the piece. While genre did not dictate the writing process from the first time I sat down to write, communicating my purpose the way I intended depended on finding the right genre. I worked on the memoir over a few years, and in that time the text began as a short story and then morphed to poetry, an essay, and finally, to a memoir. Once a completed work is published, the labelling of that work is then out of the writer's hands. Yet separate to the role genre plays in selling books, genre is key in text construction and a tool that writers have at their disposal during the writing process to enrich their work.
\end{abstract}

BIOGRAPHICAL NOTE

Raelke Grimmer is a lecturer at Charles Darwin University and a creative writing $\mathrm{PhD}$ candidate at Flinders University. Her thesis explores Australia's monolingualism and multiculturalism and the role of genre in the writing process. 
KEY WORDS

Genre-writing process-practice-led research-memoir-creative writing

Genres are used to categorise works according to structure and thematic elements. This enables readers to find books they enjoy and helps booksellers and publishers to sell more books (Murfin and Ray 2009). Yet many writers resent having their work categorised in this way and reject the construct of genre as unnecessarily relegating their work into a particular box (Atwood 2011; Gaiman and Ishiguro 2015). However, genre is also a tool that writers can use in the writing process, as different genres have different social purposes and assist the writer in communicating their purpose (Halliday and Hasan 1985; Grimmer 2017). Genre labels change not only between a writer's understanding of their work's genre and a reader's or publisher's understanding of a work's genre, but also during the writing process, as writers experiment with different genres to find the one best suited to their purpose.

This practice-led study analyses the evolution in genre of what became a memoir. The genesis of the memoir arose from a desire to articulate my own experiences of grief and mourning. I worked on the memoir over seven years. It began as a short story, before becoming a collection of poetry, an essay, and finally a memoir. To communicate my idea the way I intended, part of my writing process was to find the right genre for the idea. I initially rejected memoir, but through drafting different versions of the idea it became clear that memoir was the genre I required to clearly communicate my purpose. This paper will demonstrate, through a practice-led approach, how I used genre as a tool in the construction of my memoir. Using genre in this way is separate and distinct from the labels applied to completed works and is a core part of the writing process.

Practice-led research is a common approach adopted by creative arts researchers. Green writes that 'certain kinds of knowledge can be created only through practice' and 'it is through the practice of creative writing that new knowledge about the art of creative writing is developed, and knowledge about the contribution of creative writing to contemporary society' (2006: 176 - 7). Harper further writes that 'creative writing practice can be defined as actions or 
as a set of acts, often referred to as 'process' and leading to the completion, partial completion or sometimes the temporary abandonment of a piece of creative writing' (2008: 161). The development of my memoir illustrates how my intention as a writer influenced the genre chosen to communicate the idea, and thus investigates how writers use genre as a tool in the writing process.

\section{Background}

Genre is used and defined in different ways in different contexts, and there is no universally agreed upon definition of what genre is (Halliday and Hasan 1985; Wilkins 2005; Whitney, Ridegman and Masquelier 2011; Grimmer 2017). In this context, 'form' is used to refer to the generic text type: fiction, nonfiction, poetry. 'Genre' is used to refer to the different structures within each form: short story, sonnet, essay, memoir. These definitions draw on applied linguistics' conceptualisations of genre (see Halliday and Hasan 1985; Grimmer 2017; Melissourgou and Frantzi 2017).

While genre is a tool that writers have at their disposal during the writing process, there are writers who resent the categorising of their works into genres and thus reject the notion of genre altogether. Margaret Atwood and Kazuo Ishiguro are two writers who have vocally dismissed claims of their works being categorised as science-fiction and fantasy respectively. Writer Ursula Le Guin reported that Atwood denied her works are science-fiction, yet Atwood argued that her interpretation of science-fiction differed to Le Guin's definition, and that was why she renounced the genre (Atwood 2011). Ishiguro argued that the inclusion of fantasy elements in his work did not mean that his work is a work of fantasy (Gaiman and Ishiguro 2015). While both of these discussions are valid, each one fails to acknowledge the role a writer's knowledge of genre plays in the writing process, and how genre is used in the writing process. No writer approaches a piece of writing unburdened by the writing that came beforehand. As different genres have different social purposes, choosing which genre, or which elements of a genre, to use, is key in clear communication of the idea (Grimmer 2017). Therefore, the genre of a piece of writing is not arbitrary, but is dictated by the writer's purpose.

\section{Purpose}

My purpose was to communicate my experience of grief and mourning. When I was nine, my father had a stroke and was diagnosed with cancer. He passed away one year later. At the time, while I knew what death was, I had no understanding 
of the implications of death. My mother explained that death is forever. While I understood that, what I couldn't fully understand was the concept of forever. At ten, I didn't grasp that death meant no father at my school and university graduations, or at my wedding, or that any future partners and children would never know their father-in-law or grandfather. These revelations came to me in bursts over the next ten years. In my writing, I wanted to encapsulate this experience of grief. My purpose was to examine what grief and mourning look like years after the event, when the overwhelming despair of the moment has dissipated to something more bearable.

\section{The short story}

Initially, I attempted to achieve my purpose through a short story, as I had to write a short story for my studies. Virk writes that 'although we all read short stories and know what they are, any attempt at theoretical determination and conceptual definition leaves us confused' (2011: 248). While defining the short story depends on the cultural context, Beevers examined the work of other scholars looking at the short story and came to the understanding that a short story is characterised by the following traits:

1. generally between 2000 and 10,000 words;

2. a complete narrative too short to be published by itself;

3. deals with one aspect of life;

4. short literary prose fiction;

5. tells of something that happens to someone; and

6. implies a larger world beyond what transpires in the story (Beevers 2008: $20-21$ ).

Beevers also acknowledges that if some short stories fall outside of these characteristics, 'it doesn't much matter. We know what we mean by and large, and by and large that will suffice' (2008: 21). Beevers's understanding of a short story captures my understanding of the genre in my cultural context, and below is an extract from my attempt to fictionalise my experience:

Had it happened one or two years later, the outcome would have been completely different. At ten and eleven we were edging towards the unstable teenage years but not quite there yet; same as our childhood was being left behind. I hate how death is portrayed in books and movies as being the thing that starts people spinning a web of destruction. You can tell the authors and filmmakers who have no idea from the ones who 
understand it. The people who know realise it's something deeper, much deeper, than just the death. The ones who don't leave it at death. Death as the motivation for the characters' decline into alcohol and drugs. Don't be stupid. So many people do that kind of stuff. Not everyone is mourning for a loved one. In fact, I'm sure most of them aren't. But I'm probably too young to know.

We get off the bus, laughing. We can't remember what we're laughing at anymore, but that's beside the point.

'There's James!' Sara points across the street. We haven't done anything outside of school for ages. Once Lana shows up we set off down the road, not sure where we're headed. The sun is masked by clusters of clouds, but enough shines through to make it seem like a much nicer day than it really is. It's a Friday afternoon, and while a weekend of studying lies ahead of us, for now we have all the time in the world.

'You guys are coming to the party tonight, right?' Sara asks.

'Hell yes!' Lana cries. 'My vodka has been waiting patiently in my room for days.'

'Like it would survive that long unopened in your room,' James says. 'I got mine last night.' I drift in and out of attention. The gossip is mildly amusing but I'm not going to the party. I'm not going to waste the night. I have an essay due next week and a Spanish test on Tuesday and an allday musical rehearsal on Monday. Sunday, I need to study, Saturday I've got netball and tonight when I get home I need to put on the washing and-

Sara, James and Lana burst out laughing. I look around, confused.

'What's so funny?' I ask.

My aim with the short story was to explore what grief looks like years after the event, so I centred the narrative on a teenage girl out with her friends, who struggles to stay present as her mind wanders. I received strong feedback that there was no clear narrative in the story. While my narrative 'implied a world beyond what transpires in the story', by referring back to my protagonist's past without directly narrating it, I also removed my protagonist from the presentday narrative, instead of including her in that narrative. Therefore, my story was not 'tell[ing] of something that happens to someone', but reminiscing on an event that the reader is not privy to experiencing. This diminished the effect of the short story and made it a weak piece of writing. Through the action of 
writing the short story, it became clear that the idea I wished to explore did not easily translate to the characteristics of a short story. I was therefore unable to clearly communicate my purpose, and thus decided to try a different genre for my idea.

The English sonnet

After the short story, I left the idea for almost a year and, after studying poetry, I thought poetry would better fit my purpose. The short story I had written was segmented, and the fictionalisation had not worked. In poetry, whether the ideas were fiction or not could be ambiguous: I did not have to give anything away. Moolman writes that 'how a poem functions constitutes, affects, shapes our understanding of what a poem is' (2015: 125). He further explains that poetry is its own language, governed by its own meanings and grammars. Moolman described his experiences of showing students how to let their poems take their own directions: 'allow the words, the actual language itself to suggest the direction for the poem, its meaning, its form' (2015: 128). He wanted his students to let their poems say what they wanted to say, rather than what the students wanted them to say, and is adamant that this is a core part of poetry. On the other hand, John Leonard, former poetry editor at Overland, disagrees. He believes that it is a poet's responsibility to ensure a poem 'means what [they] want it to mean' and that the way the poem is constructed on the page conveys that meaning (Leonard 2007). I experimented with different types of poetry and wrote a small collection of fifteen poems about grief and mourning. One of the poems was an English sonnet:

The Magic Makers

Fingertips erupt in flames of magic

Unleashing a flurry of rage

Empowering his loyal sidekick

Together they strike and engage

Each rendered silent without the other

Both stripped of their sustenance

His fingers twitch when he's with another

Her beauty unadmired hence.

His eternal departure is unthinkable 
She can't know his magic is trapped

With no way of preventing the inevitable

Their fiery passion is hacked.

She waits, the Hammond organ, to be reunited

The past, the magic, never to be reignited.

I chose to write an English sonnet after attempting free form poetry because I like the creativity forced from the genre's rigid structure: an English sonnet consists of three four-line stanzas with an abab cdcd efef rhyme scheme, and then a final rhyming couplet $(g g$ ) with a dramatic ending (Shrank 2008; Holton 2010). Strictly, an English sonnet also uses iambic pentameter, but my sonnet does not follow this rhythm in every line.

The sonnet works, yet it is an abstract interpretation of my original idea. My father was a musician and played the Hammond organ. There is still one in the garage at my mother's house. I thought about this beautiful instrument, gathering dust, waiting to be played again, and it was this idea that manifested into the poem. It does touch on grief, yet I have depersonalised my experiences and transferred the grief to an inanimate object. In letting the sonnet say what it wanted to say rather than shaping it into saying what I wanted it to say, I found myself unable to express the personal aspect the way I wanted to through poetry. This is where Leonard's advice comes in-perhaps I could have persisted with the sonnet until I could get it to say what I wanted it to say. Yet the idea in the sonnet works. If I were to edit it further, I would keep the idea, and not force it into what I set out to explore.

The sonnet conveys an aspect of what I wanted to explore, and the sonnet is the most successful of the suite of poems I wrote on this topic. Yet there is a distance in the sonnet that emerged through the writing of it, which skews the aspects of grief I wanted to examine. To me, this was an indication that poetry too was not the right fit for my purpose.

The essay

After the poetry, I saw that distancing myself from the ideas in the form of a short story or poetry was distorting the perspective I wished to convey, and I needed to be closer to the writing to adequately explore this aspect of grief and 
mourning. I began to think that an essay could serve this purpose: it would allow me to incorporate the essentials of my personal experience, but still leave room for analysis of grief and mourning. Freeman and Le Rossignol write that 'the essay is developing as a resonant form of storytelling for a growing audience prepared to explore the emotional and intellectual themes arising from a writer's personal experience' (2015: 386). Tredinnick does not differentiate between an essay and a personal essay as he believes all essays need to be personal (2011). He describes four characteristics of essays and claims that if a piece of writing does not have the following attributes, it is not an essay:

1. truth-it is about something real;

2. it has a personal voice and it is authentic;

3. it 'wanders' and 'wonders'-a good essay takes the reader on the journey to the end point and is 'open-minded' in the way it attempts to unravel the topic; and

4. it is modest: 'One must never show off, and yet one must not be afraid' (Tredinnick 2011: 63).

The combination of the 'emotional and intellectual themes' is what I aimed to achieve by 'tak[ing] the reader on the journey to the end point':

I am walking home from the train station when a panel van zooms past. The train station is not my usual one but the electricity is out on my line so my choices were to use one of the lines which still endures diesel engines and walk the twenty-five minutes home or catch a bus in peak hour traffic. The train is always the preferable option. I am walking home with my earphones in, enjoying the music I only recently updated on my phone. Finally, I have something to listen to other than the random mix of songs I worshipped in my high school years. The sun beats down, surprisingly warm, and I strip off layers of jackets and scarfs as I lose myself inside my own mind. I hardly know where my mind is wandering and it is a relief to be free of conscious thinking. Then the panel van zooms past and the familiar sound snaps me back to reality, no, back to the past; it is a sound preserved from my childhood. I am walking out of the school gates after school with my brother and we are excited because it is Monday, the one day of the week that Dad picks us up. He is inevitably late, but we don't mind. He always comes eventually. We hear his panel van before we see it and we race each other to the car. It is old and rusty; a navy blue paint job to cover its lime green glory days is incapable of making the inside luxurious. I am the younger one, so my seat is the makeshift middle seat made of foam wedged between Dad in the driver's seat and my brother in the passenger seat. There is a seatbelt there for me. 
Dad dreamed of upgrading the front of the vehicle to a bench seat built for three. Secretly, I loved my improvised seat. It sat up a little higher than my brother's. The sound of the panel van disappears in the distance and I find myself walking down the street again, a little closer to home, music in my ear, my heart a little sore and the air slightly cooler.

'Sorrow' is the best word I can find for that period after grief, after mourning. The intensity lowers and stabilises after a period of time. But the burning sensation never quite leaves. It is always waiting in the wings, ready to fire again at a moment's notice. It has been almost sixteen years since my father passed away and the more time that passes, the more surprised I get that there is no word that expresses the simmering sorrow which remains for a lifetime. That is exactly what it feels like: carrying a tightly wrapped package of sorrow around in my pocket. It is difficult to predict what will create a tear in the package and allow the ballet to begin.

The excerpt includes aspects of a personal essay, yet when I re-read it, it doesn't feel authentic. I don't see truth in what I have written. Perhaps it is 'afraid', as Tredinnik suggests an essay cannot be, which has led to me recreating a fictional, watered down version of myself. Klaus writes that the 'I' in a personal essay is not necessarily the 'I' of the person writing the essay. He clarifies that he is not suggesting that the writers of personal essays are misleading readers, but that they perhaps use an alter ego to express their thoughts (2014: 2). Therein lies the missing aspect of my essay: there is an ' $\mathrm{I}$ ' in my personal essay, yet it reads as though I am fictionalising and writing someone else's personal essay. I have used the word 'I', but doing so in itself is not enough. The personal and the analysis do not seamlessly integrate, and the essay ends up reading like a half-hearted memoir and a half-hearted critical analysis, thus not achieving my purpose.

\section{The memoir}

My failed essay attempt got me thinking about memoir again. Cohen writes that 'memoir is a narrative essay, organized around a single theme, topic or situation which uses selective aspects of the life history, often combined with other material, to explore it in depth' (2012: 176). Larson agrees with this view of memoir, and notes that a key feature of memoir, and the aspect that differentiates it from autobiography, is that memoirs focus on one aspect of a person's life, rather than their whole life (2007). This means that memoirists are writing about the 'immediate past' and the 'still-corruptible present', without the added layer of time to reflect and permeate on past experiences (Larson 2007). Reflecting on 
this idea, it becomes clear that as my purpose for the piece of writing was to write about the ongoing grief, rather than immediate grief, the memoir suits that purpose: I was writing about an incident in the past, yet my focus was on the evolving nature of grief, and therefore the focus is on the present. Even though memoir is the construction of a personal narrative, I resisted the genre further by initially writing in the third person:

He held her tight, his arms encasing her, his fingers keeping her steady. She gripped his neck, skinny little arm thrown carefully around his stubbly throat, and braved deeper waters. Water gushed, leaping over rocks, spiralling into the vast basin of the desert's tropical haven.

'Daddy!' She held on tighter.

'Close your eyes.'

She didn't stop to consider the motives behind this command; there had never been any reason for her to question her unwavering trust. She squeezed her eyes shut and felt a torrent of water douse her; heard the rumble as it fell down in a continuous sheet.

This brief memory is from when I was two years old. Even so, in an attempt to distance myself from the writing, I did not want to use the first person. This choice was perhaps informed from my failed attempt at using ' $I$ ' in the essay, yet the third-person perspective only serves to distance the reader from the narrative, especially in a memoir, where the expectation is that it will be written in the first person. There are exceptions, such as Salman Rushdie's Joseph Anton. Wesley argues that Rushdie writes in the third person singular in order to emphasise the split between selves' (2017: 525) in the different chapters of his life. Yet for my memoir, the third person does not work: it is a personal experience and trying to pretend otherwise diminishes both the narrative and my experiences. I was halfway through my first draft before I realised that while the style, format and genre felt right, I needed to use the first person:

'Close your eyes.'

From above, water gushed, leaping over rocks, spiralling into the vast basin of the desert's tropical haven. Dad held me tight in the centre of the swimming hole, his tanned arms protecting me, his fingers firm on my waist. I gripped his neck, skinny little arms a lifeline around his stubbly throat, and braved deeper waters. 
'Daddy!' I tightened my grip as he carried me through the calm of the swimming hole towards the waterfall. I didn't want to be trapped beneath a thick wall of falling water.

'Close your eyes.'

I didn't stop to consider the motives behind this command; in my two and a half years there had never been a reason for me to question my unwavering trust. I squeezed my eyes shut and felt a torrent of water douse my entire body. Then nothing but the rumble of moving water as it fell down in a continuous sheet.

\section{'Open your eyes.'}

I was afraid. Afraid the water would send me blind, afraid of where I'd be. Yet if he told me to, I knew it must be okay. I opened my eyes and Dad looked back at me, smiling, still holding me close. Where were we? What had happened to the waterfall? I drew my eyes from my father's and breathed in our surrounds, enchanted. We drifted in our own private utopia, sheltered by flat rock on one side and a moving wall of liquid glass on the other. We were inside the waterfall; together in the space left untouched by the curve of the falling water. Water surrounded us but couldn't rain down on us. We were untouchable. The gentle roar of the water coloured our new world with music. It was my first taste of magic; the first I knew of my father as a magician.

Too soon, Dad whispered, 'Close your eyes.'

And we stepped back through the vortex, to a world where people apart from my father and me existed.

Once I changed the voice, the personal engagement with the reader immediately came through. The memoir combined with the first person created the authentic 'I' that was missing in the essay. Furthermore, I chose to use a vignette style in the memoir, which allowed me to communicate the fragmented and random nature of memories through structure, rather than the words on the page. This aspect developed through my process of experimenting with the original short story and the poetry. The final iteration of this idea maintains aspects of all of my previous drafts in different genres. It is through the process of trying different genres on for size that the final version sits within the memoir space. 
Conclusion

I did not set out to write a memoir. I wanted to write about an aspect of grief I felt was underrepresented. In my process of constructing that idea on the page, I used genre as a tool to shape and reshape my writing and refine my idea in order to find the form, genre and structure that best suited the idea I wanted to communicate. That process of change and experimentation with genre enabled me to find memoir as the genre that enabled me to clearly capture the experience of ongoing grief, and this process of change is a key aspect of the writing process. To me, the final version sits within memoir, but once the writing is complete and handed over to readers, it is no longer mine to label. Genre then changes its role as publishers and booksellers use genre to attract readers. This labelling is out of the hands of the writer, and it is this aspect of genre that serves to corner works into unhelpful boxes. Yet despite this function of genre, when writers use genre as a writing tool, it has the capacity to enrich the writing process and positively impact the construction of a work. 
Works Cited

Atwood, Margaret 2011 'The road to ustopia' The Guardian 15 October, at https://www.theguardian.com/books/2011/oct/14/margaret-atwood-road-toustopia (accessed 3 October 2017)

Beevers, John 2008 'The short story: what is it exactly, what do we do with it, and how do we intend to do it?' in A Cox (ed) The Short Story Newcastle upon Tyne: Cambridge Scholars Publishing, $11-26$

Cohen, Phil 2012 'Recognizing in the inferno in that which is not: reflections on writing a memoir' History Workshop Journal 74 (1), 173 - 191

Freeman, Robin and Karen Le Rossignol 2015 'Disruption and resonance in the personal essay' New Writing: The International Journal for the Practice and Theory of Creative Writing 12 (3), $384-397$

Gaiman, Neil and Kazuo Ishiguro 2015 “'Let’s talk about genre” Neil Gaiman and Kazuo Ishiguro in conversation' New Statesman 11 May, at http://www.newstatesman.com/2015/05/neil-gaiman-kazuo-ishigurointerview-literature-genre-machines-can-toil-they-can-t-imagine (accessed 8 November 2017)

Green, Lelia Rosalind 2006 'Creative writing as practice-led research' Australian Journal of Communication $33(2,3) 175-188$

Grimmer, Raelke 2017 'Rethinking genre: genre as a tool for writers throughout the writing process' Writing in Practice 317 March, at https://www.nawe.co.uk/DB/current-wip-edition-2/articles/rethinkinggenre-genre-as-a-tool-for-writers-throughout-the-writing-process.html (accessed 8 November 2017)

Halliday, Michael Alexander Kirkwood and Ruqaiya Hasan 1985 Language, context and text: Aspects of language in a social-semiotic perspective Melbourne: Deakin University Press

Harper, Graeme 2008 'Creative writing: words as practice-led research' Journal of Visual Art Practice 7 (2), 161 - 171

Holton, Amanda 2010 'An obscured tradition: The sonnet and its fourteen-line predecessors' The Review of English Studies 62 (255), 373 - 392

Klaus, Carl 2014 The Made-Up Self: Impersonation in the personal essay, Iowa City: University of Iowa Press

Larson, Thomas 2007 The Memoir and the Memoirist: Reading and Writing Personal Narrative Athens: Ohio University Press

Leonard, John 2007 'The practicalities of writing poetry' Overland 186 (autumn), 67 $-69$ 
Melissourgou, Maria and Katerina Frantzi 2017 'Genre identification based on SFL principles: The representation of text types and genres in English language teaching material' Corpus Pragmatics 1 (4), 373 - 392

Moolman, Kobus 2015 'Teaching the practice of writing poetry in an academic environment' Current Writing: Text and Reception in Southern Africa 27 (2), 124-131

Murfin, Ross and Supriya Ray 2009 The Bedford Glossary of Critical and Literary Terms ( $3^{\text {rd }}$ ed) Boston: Bedford/ St Martin's

Shrank, Cathy 2008 “"Matters of Love as of Discourse”: The English sonnet, 15601580' Studies in Philology 105 (1), $30-49$

Tredinnick, Mark 2011 'The lyric stance’ Island 126 (spring), 60 - 70

Virk, Tomo 2011 'The short story as a genre of ontological uncertainty' Forum for World Literature Studies 3 (2), 248 - 254

Wesley, Charlie 2017 'Salman Rushdie's authorial self-fashioning in Joseph Anton' The Journal of Commonwealth Literature 52 (3), 519 - 533

Wilkins, Kim 2005 'The process of genre: authors, readers, institutions' TEXT 9 (2) October, at http://www.textjournal.com.au/octo5/wilkins.htm (accessed 11 May 2016)

Whitney, Anne Elrod, Michael Ridgeman and Gary Masquelier 2011 'Beyond "is this OK?": high school writers building understandings of genre: for writers, understanding genre means understanding forms, structure, rhetorical devices, and how to write effectively in school and beyond' Journal of Adolescent and Adult Literacy 54 (7), 525 - 535 